\title{
DRIVERS AND BARRIERS FOR E-BUSINESS: EVOLUTION OVER TIME AND COMPARISON BETWEEN SMES AND LARGE COMPANIES
}

\author{
Dirk Deschoolmeester ${ }^{1}$, Evelyne Vanpoucke ${ }^{2}$ and Peter Willaert ${ }^{3}$ \\ ${ }^{1}$ Vlerick Leuven Gent Management School, Reep 1, 9000 Gent, Belgium, \\ dirk.deschoolmeester@vlerick.be; ${ }^{1}$ Faculty of Economics and Business Administration, \\ Hoverniersberg 24, 9000 Gent, Belgium,dirk.deschoolmeester@ugent.be; ${ }^{2}$ Vlerick Leuven \\ Gent Management School, Reep 1, 9000 Gent, Belgium, evelyne.vanpoucke@vlerick.be; \\ ${ }^{3}$ Vlerick Leuven Gent Management School, Reep 1, 9000 Gent, Belgium, \\ peter.willaert@vlerick.be
}

Abstract: The ups and downs of e-business investments are related to a hype cycle. This hype cycle strengthened the statement that companies are too willing to believe in the promises of the new Internet economy without really thinking about internet-ability. According to the data in this practice-oriented survey work, SMEs are more eager to follow the e-business hype cycle. We try to give some explanations for these differences in e-business between SMEs and large companies. This requires an examination of the planning, the drivers and the barriers for conducting business processes over a computer-mediated network. We found that larger companies are mainly driven by cost-cutting to implement e-business, while SMEs attach, next to cost-savings, high importance to cooperation between their suppliers and clients. Furthermore, we can observe that larger companies see more opportunities in translating their ebusiness strategy into a formal long-term plan. This explains perhaps why larger companies are less trend sensitive for investing in e-business than SMEs.

Key words: e-business hype cycle, IT investments, SME, CADIGA-rule, internet-ability 


\section{PURPOSE OF THE SURVEY}

In order to collect the data to understand the e-business use and readiness of Belgian companies, four surveys have been conducted over a period of time (1999-2002). In this survey we assessed in the first place the current status of e-business in the companies. To investigate the process of organizing a business over a computer-mediated network, it was analyzed whether companies located in Belgium find it important to have a strategic e-business plan and whether these companies also have developed such a formal plan.

It was also thought to be useful to make a deeper study on the drivers for implementing Internet technologies and on the impediments or barriers hindering the adoption of Internet technologies for small and large companies.

Resistance, pressures and barriers for e-business were investigated and reclassified in 5 main categories. In order to identify the drivers for ebusiness, we asked for the expected organizational and strategic impact of ebusiness and its benefits. The drivers were classified based upon what the authors further define as the CADIGA framework (a further development and adaptation of Wiseman's work on strategy and IT, 1985, Figure 3). These themes were part of what has been called Internet-ability by the authors of this survey work and are also an important input for adoption stages models (Scupola, 2002).

After taking a closer look to the general evolution of e-business for all Belgian companies, a particular interest is paid in this practice-oriented survey work to whether small and medium sized companies show relevant differences in their Internet-use and -readiness compared with larger companies (criterion: total employment lower (SMEs) than 500 persons and higher (large companies) than 500 persons, European Parliament definition (OECD, 1999)). A comparative analysis of drivers and barriers in large companies and SMEs was also conducted.

Survey data of 235 companies, collected in the period 1999-2002 was used to investigate Internet-ability in Belgian companies. As well descriptive statistics, as explanatory statistical analysis were performed to test the reliability and validity of our findings.

\section{E-BUSINESS FOLLOWS A HYPE-CYCLE}

By looking at how many Belgian companies have a strategic e-business plan and how important it is to have one, we can see that e-business follows a hype cycle. During the early adoption stage, i.e. for this study in 1999, only $30 \%$ of the companies had an e-business plan. Since 2001 however, nearly $50 \%$ of the Belgian companies had already some sort of strategic e- 
business plan formally written down (Table 1). On the other hand, the study shows that slightly more than $50 \%$ of the Belgian companies do not have such a plan!

Table 1. Belgian companies holding a formal e-business plan (1999-2002)

\begin{tabular}{cccc}
\hline \multicolumn{4}{c}{$\%$ of companies with a strategic e-business plan (1999-2002) } \\
\hline $1999(\mathrm{~N}=78)$ & $2000(\mathrm{~N}=56)$ & $2001(\mathrm{~N}=52)$ & $2002(\mathrm{~N}=49)$ \\
$\%$ of companies with & $\%$ of companies with & $\%$ of companies with & $\%$ of companies with \\
a formal e-business & a formal e-business & a formal e-business & a formal e-business \\
plan & plan & plan & plan \\
$29 \%$ & $33 \%$ & $48 \%$ & $47 \%$ \\
\hline
\end{tabular}

The importance that companies attach to a formal e-business plan (Figure 1) increased in the first two years and is in a later period followed by a decrease. In 2000, already $91 \%$ of the companies believed in the importance of having an e-business strategy. A similar increase in companies holding such a strategic e-business plan (Table 1) confirmed this statement. However, the belief that a formal plan is needed decreased after the year 2000. The reaction came later: since 2001 the amount of companies writing down an ebusiness plan felt slightly back. This increase followed by a decrease indicates that e-business follows a hype-cycle with a peak in 2000: when the hype was over, the urgent need to formally plan in several companies was apparently gone.

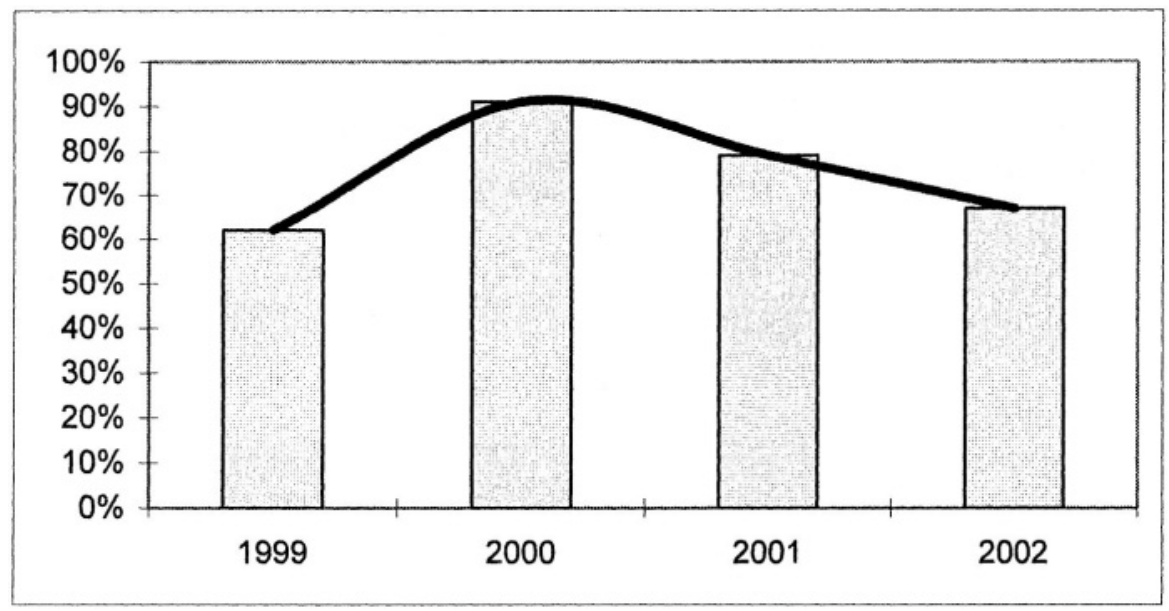

Figure 1. \% of companies that find a formal e-business plan important (1999-2002) 
If the results are split along the lines of company size, we can find that small and medium-sized companies show an emerging, especially widening lag in their formulation of an Internet strategy (Table 2, Figure 2).

Table 2. Companies holding a formal e-business plan (1999-2002)

\begin{tabular}{lcccc}
\hline & $\begin{array}{c}1999(N=78) \\
\% \text { with a formal } \\
\text { e-com strategy }\end{array}$ & $\begin{array}{c}2000(N=56) \\
\% \text { with a formal } \\
\text { e-com strategy }\end{array}$ & $\begin{array}{c}2001(N=52) \\
\% \text { with a formal } \\
\text { e-com strategy }\end{array}$ & $\begin{array}{c}2002(N=49) \\
\% \text { with a formal } \\
\text { e-com strategy }\end{array}$ \\
\hline SMEs & $26 \%$ & $27 \%$ & $37 \%$ & $33 \%$ \\
Large enterprises & $31 \%$ & $36 \%$ & $55 \%$ & $68 \%$ \\
\hline
\end{tabular}

This widening gap can be better understood when asking companies' response on how important it is to have a formal e-business plan. The graph below shows that there exists a large gap between the perception on the importance of e-business plans for larger and smaller companies today. The lower interest and/or lower "Internet-ability" of SMEs are seen as the main reasons for this gap. Remarkable is again the peak in 2000 , which can be explained by the hype around doing e-business in 2000 and by the fact that the falldowns in active interest are higher for SMEs than for larger companies.

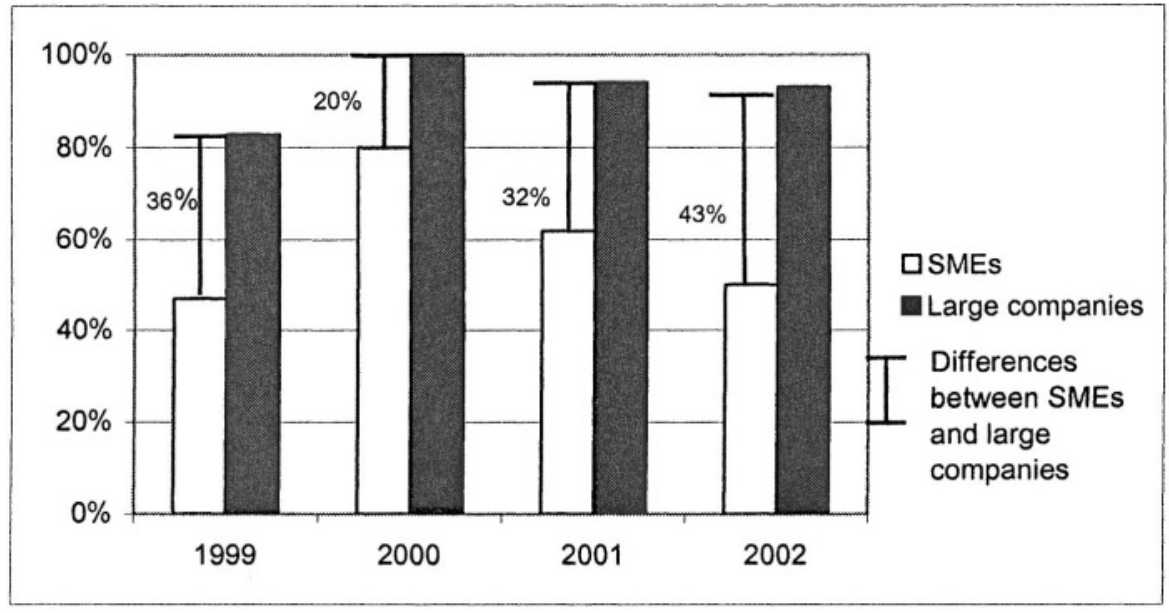

Figure 2. The importance of a formal e-business plan (1999-2002)

Since it can be assumed that the lack of explicit strategy formulation - being used as a guideline for future e-investments - poses one of the major barriers for the adoption and implementation of these Internet technologies, the relative lack of SMEs in formulating a strategic e-business plan can be considered as a major reason why SMEs are tending to lag behind in effectively 
implementing these more advanced technologies for information processing and communication. Large companies do not only provide a variety of eapplications such as catalogues, on-line surveys, ordertaking, marketing and procurement via the internet, they also use IT for processing the orderrelated transactions (ordertaking and payment) and providing customers with detailed information.

The European Commission claims that e-business in Europe is hampered by a lack of trust. Although $66 \%$ of small companies have Internet access in Europe, only $6 \%$ of these small European companies transact business online in real-time. (Jutla en Weatherbee, 2002) The same conclusion can be drawn for Belgian SMEs in this study: only $6 \%$ of the transaction processing is done by the Internet (Table 3).

Table 3. The use of Internet technologies in SMEs and large companies (2002)

\begin{tabular}{lcccccc}
\hline \multicolumn{3}{c}{ Internet technologies for SMEs and large companies in 2002 } \\
\hline & \multicolumn{3}{c}{ Realized } & $\begin{array}{c}\text { Planned for } \\
\text { within 1 year }\end{array}$ & $\begin{array}{c}\text { Planned for } \\
\text { later than 1 } \\
\text { year }\end{array}$ \\
E-applications & & & & \multicolumn{4}{c}{$\begin{array}{c}\text { SME } \\
\text { (SME: N=30, Large: N=19) }\end{array}$} & SME & Large & SME & Large & SME & Large \\
\hline Catalogue of products and services & $79 \%$ & $69 \%$ & $21 \%$ & $19 \%$ & $0 \%$ & $12 \%$ \\
On-line survey & $50 \%$ & $46 \%$ & $29 \%$ & $39 \%$ & $21 \%$ & $15 \%$ \\
Handling requests for proposals & $52 \%$ & $33 \%$ & $16 \%$ & $34 \%$ & $32 \%$ & $33 \%$ \\
Ordertaking and handling & $45 \%$ & $43 \%$ & $25 \%$ & $21 \%$ & $30 \%$ & $36 \%$ \\
Access to forums and newsgroups & $24 \%$ & $36 \%$ & $38 \%$ & $7 \%$ & $38 \%$ & $57 \%$ \\
After-sales-service & $25 \%$ & $50 \%$ & $54 \%$ & $14 \%$ & $21 \%$ & $29 \%$ \\
Prospecting and direct marketing & $41 \%$ & $43 \%$ & $27 \%$ & $28 \%$ & $32 \%$ & $29 \%$ \\
Co-managed inventory & $18 \%$ & $10 \%$ & $9 \%$ & $10 \%$ & $73 \%$ & $80 \%$ \\
Vendor-managed inventory (VMI) & $20 \%$ & $18 \%$ & $10 \%$ & $9 \%$ & $70 \%$ & $73 \%$ \\
E-procurement & $25 \%$ & $42 \%$ & $25 \%$ & $25 \%$ & $50 \%$ & $33 \%$ \\
\hline \multicolumn{1}{c}{ Internet technologies that are more often used by large companies than by SMEs } \\
\hline Transaction processing* & $6 \%$ & $33 \%$ & $22 \%$ & $17 \%$ & $72 \%$ & $50 \%$ \\
Search engines* & $43 \%$ & $77 \%$ & $26 \%$ & $11 \%$ & $31 \%$ & $11 \%$ \\
Access to FAQs* & $38 \%$ & $75 \%$ & $29 \%$ & $13 \%$ & $33 \%$ & $12 \%$ \\
\hline
\end{tabular}

(*) Significant difference between SMEs and large companies with a $85 \%$ confidence interval

\section{STRATEGIC DRIVERS FOR E-BUSINESS}

Besides the degree of formalization of the planning, this study was also interested in the motivations and arguments to invest in the Internet technologies. These drivers and barriers (infra) are important aspects in the adoption stages of SMEs. An example of such a stages model for SMEs is the PriceWaterhouseCoopers' model (1999). In a first stage, SMEs have certain perceptions of the opportunities and benefits (or so-called drivers) for ecommerce. In the second stage, the SMEs try to develop their e-commerce 
capabilities based on the information from the first stage. Next, the companies experience a number of barriers in the realization process which they try to solve in the following stage. They look for governments or other stakeholders to help them to overcome these barriers. If they finally see the results, they go on with developing e-commerce capabilities. As we described here, this stages model indicates that drivers and barriers have important consequences in the adoption of e-commerce and e-business in SMEs. This is also the reason why we attach a lot of importance to these drivers and barriers for e-business.

Table 4 explains the strategic reasons companies quote for adopting ebusiness. In a study of 1999 (Deschoolmeester, ea.), only a minority of Belgian companies were convinced that the adoption of the most basic Internet technologies, e.g. an online catalogue of products, would cut costs. Internet was not only seen as a way to improve the bottom-line results of the company, but also as a way to improve collaboration and differentiation.

In this research, six reasons were retained why companies build an Internet business alongside their existing one: 1) cutting costs $(\mathrm{C}), 2)$ improving internal and/or external integration and cooperation (A), 3) differentiate from competitors (D), 4) using ICT to improve innovation and its related external replication (I), 5) improve the companies position for growth (G), or 6) agility for external changes (A). This rule of thumb (CADIGA-rule) points to strategic drivers that can be attained through the use of ICT (Figure 3). The model is an adaptation made by authors on the basis of ideas from Porter (1980) and more specifically Wiseman (1985). They give business management a list of motives for investing in ICT. Also other studies argue that amongst IT-investments in general, Internet technologies have the highest potential for value-creation through linking companies, its suppliers and customers in new and innovative ways (Armit, Zott, 2001).

Zhu et al. (2002) identify six significant e-business adoption predictors, which are comparable with those included in the CADIGA-rule. These six predictors are technology competence, firm scope, firm size, consumer readiness, competitive pressure and lack of trading partner readiness. Consumer and trading partner readiness reflect the drive for alliances, the competitive pressure explains the drive for differentiation, firm size is a predictor related to the growth reason, technological competence is represented by the innovation drive and finally firm scope reflects the urge for cutting costs. 
Table 4. CADIGA-rule

\begin{tabular}{|c|c|}
\hline \multicolumn{2}{|r|}{ CADIGA-rule for investing in IT* } \\
\hline $\begin{array}{l}\text { (C) } \\
\text { CUTTING } \\
\text { COSTS }\end{array}$ & $\begin{array}{l}\text { A lot of companies implement an Enterprise Resource Planning (ERP) } \\
\text { to obtain a more productive procurement- and production planning. In } \\
\text { this way they can achieve smaller inventories of resources, work in } \\
\text { process and finished products. They can also achieve a more optimal use } \\
\text { of production-resources through efficient information processing, } \\
\text { smaller teams of purchasers and production planners. }\end{array}$ \\
\hline $\begin{array}{l}\text { (A) } \\
\text { ALLIANCES: } \\
\text { Internal: integra- } \\
\text { tion } \\
\text { External: coop- } \\
\text { eration } \\
\end{array}$ & $\begin{array}{l}\text { Integration between functional domains via central databases and the } \\
\text { coordination of activities in an integrated process are made possible with } \\
\text { the aid of ICT. } \\
\text { In an extended enterprise, suppliers and customers can cooperate non- } \\
\text { stop and in real-time thanks to the new ICT. }\end{array}$ \\
\hline $\begin{array}{l}\text { (D) } \\
\text { DIFFEREN- } \\
\text { TIATION } \\
\text { FROM COM- } \\
\text { PETITORS }\end{array}$ & $\begin{array}{l}\text { Via Internet Web browsing, the customer can place his order and buy a } \\
\text { custom-made product. The cycle-time between sales-order and delivery } \\
\text { can also be drastically reduced. Websites where these facilities are } \\
\text { available can differentiate a company from its competitors who still } \\
\text { follow the traditional way of selling. }\end{array}$ \\
\hline $\begin{array}{l}\text { (I) } \\
\text { INFORMATION } \\
\text { AND KNOWL- } \\
\text { EDGE / } \\
\text { INNOVATION }\end{array}$ & $\begin{array}{l}\text { Having the right kind of information, on the right time, available to the } \\
\text { right kind of decision-makers, is an essential task of all information } \\
\text { management. } \\
\text { If wisdom and experience are added to information, one gets knowledge. } \\
\text { Companies who create and share a lot of knowledge with the help if ICT } \\
\text { and who have a learning mentality and sharing knowledge among per- } \\
\text { sonnel will be the star players of the future. } \\
\text { If companies want to have an image of being technologically advanced, } \\
\text { ICT is one of the best means to achieve this image of being innovative. } \\
\text { Some customers and suppliers prefer working with companies who } \\
\text { prove to have a knack for innovation. }\end{array}$ \\
\hline $\begin{array}{l}\text { (G) } \\
\text { IMPROVE } \\
\text { GROWTH PO- } \\
\text { SITION }\end{array}$ & $\begin{array}{l}\text { With the help of ICT, companies can grow in size, in the number of } \\
\text { business activities or on a geographic scale. Besides quantitative growth } \\
\text { this also entails qualitative growth whereby information is more accessi- } \\
\text { ble when needed, which will eventually empower personnel. }\end{array}$ \\
\hline $\begin{array}{l}\text { (A) } \\
\text { AGILITY, } \\
\text { FLEXIBILTY }\end{array}$ & $\begin{array}{l}\text { To improve awareness on the role of ICT for the organization, higher } \\
\text { level management has to question itself on a regular basis about the } \\
\text { relationship between potential and obtained results in the past, current } \\
\text { and future ICT project portfolio. When the external environment } \\
\text { changes, adequate modification has to be made swiftly. }\end{array}$ \\
\hline
\end{tabular}

(*) Further developed and adapted by Dirk Deschoolmeester from Wiseman's work on strategy and IT (1985) and ideas from Porter (1985)

In 1999, cost-savings were seen as the main motivator for implementing Internet technologies, but cannot be the single reason for applying ebusiness. Improving alliances and flexibility are examples of other important drivers to implement these technologies in companies. By looking at the differences between small and large companies in 2002, one can see that the 
main driver for developing Internet technologies is not the same for SMEs as for large companies. While large companies are mainly motivated by the cost-saving aspect of Internet technologies (Figure 3), SMEs are in the first place driven to implement these technologies by the improvements in cooperation with their suppliers and clients (Figure 4). This is in contrast with findings in other research on SME drivers and barriers for e-business where costs are found to be a major concern (Levy, Powell, Yetton, 2003; Prananto, McKay and Marshall, 2003).

On the other hand our findings are also reflected in research of Zhu et al. (2002), which identified technology competence, firm scope and size, consumer readiness, and competitive pressure as being significant e-business adoption facilitators, while lack of trading partner readiness is a significant adoption inhibitor. Moreover this study confirms our results in claiming that in high e-business intensity countries, e-business is no longer a phenomenon dominated by large firms; as more and more firms engage in e-business, network effect works to the advantage of small firms. In this case these SMEs have more opportunities to form alliances.

Improved communication around the clock, administrative cost savings, increased efficiency and easiness to do business are the most important short-term drivers. Increased company visibility, market potential and a contribution to internationalization, on the other hand, are among the most important long-term indirect drivers (Poon, Swatman, 1999). In this study, we can conclude that SMEs and large companies focus mainly on short-term drivers.

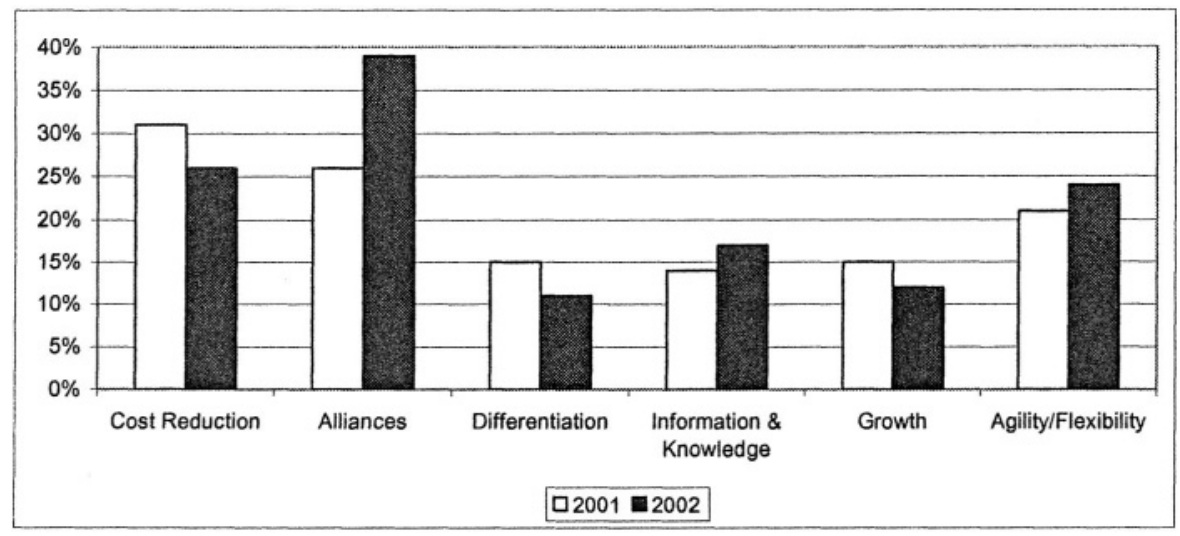

Figure 3. CADIGA-rule for Belgian SMEs (2001-2002) 


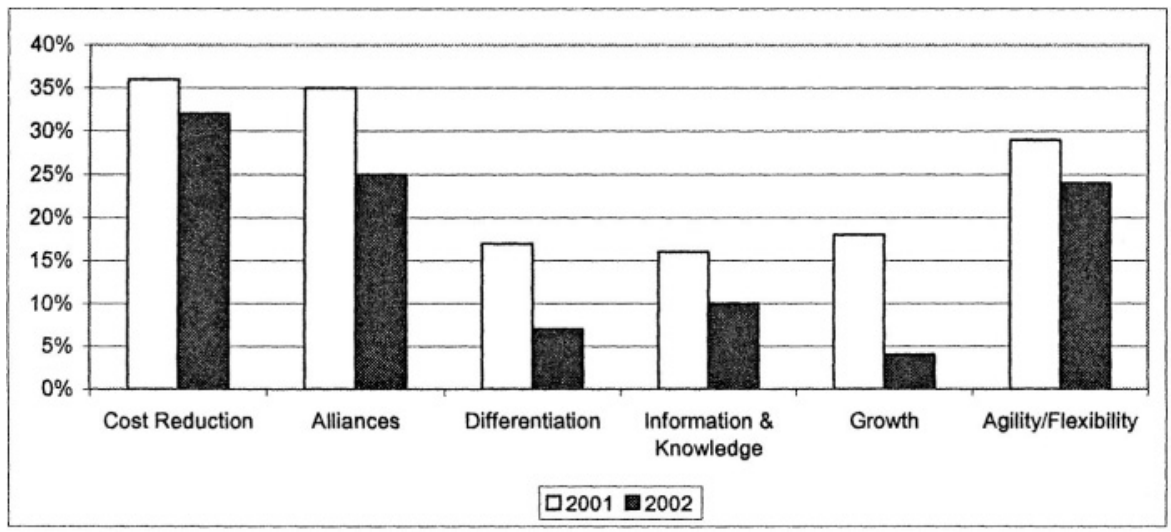

Figure 4. CADIGA-rule for large companies in Belgium (2001-2002)

While looking at the implementation of Internet technologies in SMEs and large companies, one can see some differences between SMEs and large companies in the CADIGA-rule concerning the specific application fields.

\subsection{The CADIGA-rule: growth (G)}

Some companies, especially the smaller ones, believe that Internet technologies give them opportunities to grow. The majority of large companies, on the other hand, do not often use Internet technologies for supporting growth opportunities in their company. These differences between large companies and SMEs in seeing e-business as a growth factor is situated mainly in the field of co-engineering of new products and handling requests for offers/proposals/information (Table 5). Other studies support this statement (Levy, Powell, Yetton, 2003).

Table 5. Significant differences in growth between SMEs and large companies according to their application yield

\begin{tabular}{ccc}
\hline BenefitsiCompany size & $\begin{array}{c}\text { Importance of the growth } \\
\text { driver for implementing IT } \\
\text { in small companies }\end{array}$ & $\begin{array}{c}\text { Importance of the growth } \\
\text { driver for implementing IT in } \\
\text { large companies }\end{array}$ \\
\hline $\begin{array}{c}\text { Co-engineering of new } \\
\text { products }\end{array}$ & $25 \%$ & $6 \%$ \\
\hline $\begin{array}{c}\text { Handling requests for } \\
\text { offers/ Proposals/ Quo- } \\
\text { tations }\end{array}$ & $19 \%$ & $0 \%$ \\
\hline
\end{tabular}

$\left.{ }^{*}\right)$ Significant differences between SMEs and large companies: $t$-test with a confidence interval of $85 \%$. 


\subsection{The CADIGA-rule: Flexibility (F)}

Flexibility is another important item for both SMEs and large companies. Although the way to reach this flexibility through the use of Internet technologies is different for these two groups, SMEs see Internet technologies as a tool to improve the flexibility of marketing activities, i.e. the prospecting of customers and doing surveys, whereas large companies pay more attention to the flexibility of their inventories (Table 6).

Table 6. Significant differences in flexibility perceptions between SMEs and large companies according to their application yield (2002)

\begin{tabular}{|c|c|c|}
\hline Benefits $\backslash$ Company size & $\begin{array}{l}\text { Importance of the flexibility } \\
\text { driver for implementing IT in } \\
\text { small companies }\end{array}$ & $\begin{array}{l}\text { Importance of the flexibility } \\
\text { driver for implementing IT in } \\
\text { large companies }\end{array}$ \\
\hline On-line surveys & $32 \%$ & $6 \%$ \\
\hline Co-managed inventory & $8 \%$ & $28 \%$ \\
\hline $\begin{array}{l}\text { Prospecting and direct } \\
\text { marketing }\end{array}$ & $15 \%$ & $0 \%$ \\
\hline
\end{tabular}

(") Significant differences between SMEs and large companies: t-test with a confidence interval of $95 \%$.

\subsection{The CADIGA-rule: Alliances (A)}

A third important driver for IT is the creation of alliances. One can see that small companies expect that the development of new information technologies for customer service will improve their internal and external collaboration and cooperation. In other words, SMEs believe that Internet technologies will help them to streamline and to improve the supply chain (Table 7).

Table 7. Significant differences in the perception of cooperation and collaboration between SMEs and large companies according to their application yield (2002)

\begin{tabular}{lcc}
\hline Benefits|Company size & $\begin{array}{c}\text { Importance of the coopera- } \\
\text { tion and collaboration driver } \\
\text { for implementing IT in SMEs }\end{array}$ & $\begin{array}{c}\text { Importance of the coopera- } \\
\text { tion and collaboration driver } \\
\text { for implementing IT in large } \\
\text { companies }\end{array}$ \\
\hline
\end{tabular}

\begin{tabular}{lll}
\hline $\begin{array}{l}\text { Handling requests for } \\
\text { offers/Proposals/ Quota- } \\
\text { tions }\end{array}$ & $57 \%$ & $22 \%$ \\
\hline $\begin{array}{l}\text { Offering access to FAQs } \\
\begin{array}{l}\text { Provide customer ser- } \\
\text { vice }\end{array}\end{array}$ & $80 \%$ & $50 \%$ \\
\hline
\end{tabular}

(") Significant differences between SMEs and large companies: t-test with a confidence interval of $85 \%$. 


\subsection{The CADIGA-rule: Information and knowledge (I)}

Another significant difference in the perception of information technologies between SMEs and large companies is that SMEs are convinced that using IT to develop catalogues or ordertaking processes offers large advantages in managing information and knowledge. Large companies do not share this believe (Table 8 ).

Table 8. Significant differences in the perception of "information and knowledge" between SMEs and large companies according to their application yield (2002)

\begin{tabular}{ccc}
\hline $\begin{array}{c}\text { BenefitsiCompany } \\
\text { size }\end{array}$ & $\begin{array}{c}\text { Importance of the information } \\
\text { and knowledge driver for im- } \\
\text { plementing IT in SMEs }\end{array}$ & $\begin{array}{c}\text { Importance of the informa- } \\
\text { tion and knowledge driver } \\
\text { for implementing IT in } \\
\text { large companies }\end{array}$ \\
\hline $\begin{array}{c}\text { Catalogue of products/ } \\
\text { services }\end{array}$ & $46 \%$ & $17 \%$ \\
\hline $\begin{array}{c}\text { Ordertaking from cus- } \\
\text { tomers }\end{array}$ & $18 \%$ & $0 \%$ \\
\hline
\end{tabular}

(*) Significant differences between SMEs and large companies: t-test with a confidence interval of $85 \%$.

\subsection{The CADIGA-rule: Costs (C) and Differentiation (D)}

According to costs (C) and differentiation (D), there are no real differences between SMEs and large companies.

\section{BARRIERS TO THE IMPLEMENTATION OF E- BUSINESS}

Information technology managers experience different impediments in the adoption and/or the development process of e-business. We have measured the importance of 16 potential barriers, which can be categorized by a factor analysis into 5 main e-business obstructions: rules \& standards, costs, safety \& security, know-how \& technology and lack of awareness. In 2002, costs and safety \& security are seen as the most important barriers for the further implementation of e-business (Figure 5). 


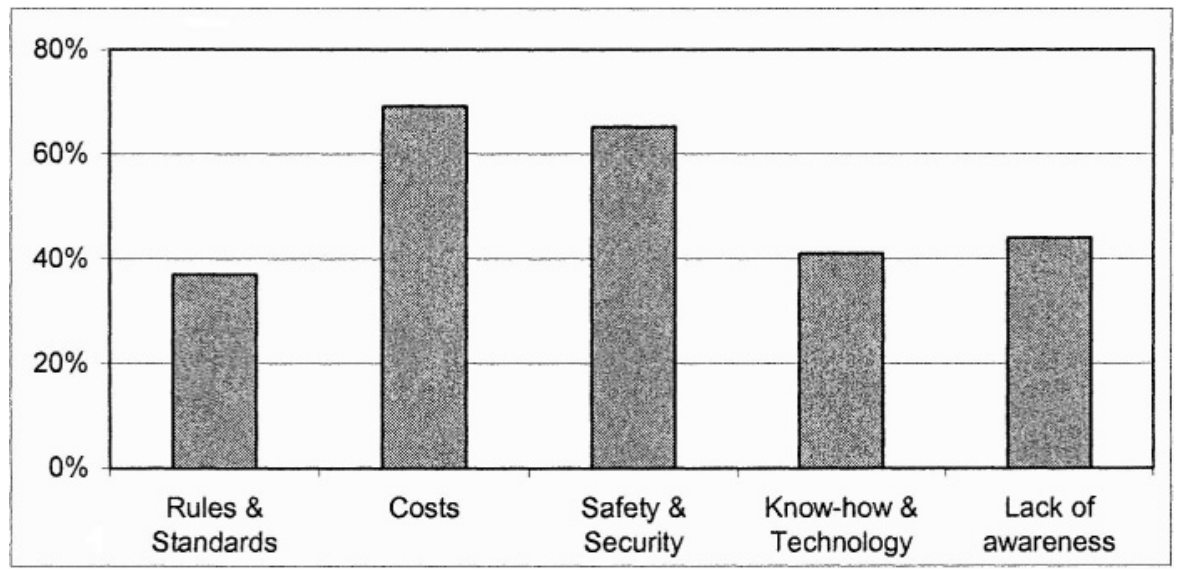

Figure 5. The five important barriers for e-business

The table below (Table 9) illustrates the evolution in the importance of the barriers. It is striking that, from 1999 until 2002, most barriers have been perceived to be less stringent. Some other barriers like security, privacy, lack of ready-to-use software, problematic integration with the existing business processes and cost barriers stayed at the same level. The general decrease of barriers for implementing Internet technologies shows that there is a positive development towards better competence for e-enabling business processes. Although barriers became less strong, we can see again that security and costs are perceived to have kept a rather high level of hindrance for companies implementing Internet technologies.

On one hand, these five factors form strong barriers for Belgian companies to implement e-business projects. On the other hand, they can also function as accelerators for competitors who are able to overcome these barriers. The reader can analyze the situation in more detail in the following table. Some variation in ups and downs might also be related to the well-know ebusiness hype cycle (supra). 
Table 9. The importance of the 16 barriers (1999-2002)

\begin{tabular}{|c|c|c|c|c|c|}
\hline & \multicolumn{5}{|c|}{ Importance of barriers } \\
\hline & $\begin{array}{c}1999 \\
(\mathrm{~N}=78) \\
\text { Very }+ \\
\text { Rather } \\
\text { important } \\
\text { barrier }\end{array}$ & $\begin{array}{c}2000 \\
(\mathrm{~N}=56) \\
\text { Very }+ \\
\text { Rather } \\
\text { important } \\
\text { barrier }\end{array}$ & $\begin{array}{c}2001 \\
(\mathrm{~N}=52) \\
\text { Very }+ \\
\text { Rather } \\
\text { important } \\
\text { barrier }\end{array}$ & $\begin{array}{c}2002 \\
(\mathrm{~N}=49) \\
\text { Very + } \\
\text { Rather } \\
\text { important } \\
\text { barrier }\end{array}$ & $\begin{array}{l}\text { Changes } \\
\left({ }^{*}\right)\end{array}$ \\
\hline \multicolumn{6}{|l|}{ Safety } \\
\hline Security & $82 \%$ & $79 \%$ & $84 \%$ & $90 \%$ & $=$ \\
\hline Privacy (on payments) & $86 \%$ & $66 \%$ & $65 \%$ & $80 \%$ & $=$ \\
\hline $\begin{array}{l}\text { Fear of cannibalizing / compet- } \\
\text { ing with your existing business }\end{array}$ & $43 \%$ & $38 \%$ & $39 \%$ & $24 \%$ & - \\
\hline \multicolumn{6}{|l|}{ Know-how \& technology } \\
\hline Language & $49 \%$ & $29 \%$ & $25 \%$ & $17 \%$ & - \\
\hline $\begin{array}{l}\text { Lack of ready-to-use software } \\
\text { solutions }\end{array}$ & $65 \%$ & $61 \%$ & $68 \%$ & $40 \%$ & $=$ \\
\hline $\begin{array}{l}\text { Lack of internet technology } \\
\text { know-how / Experience }\end{array}$ & $66 \%$ & $59 \%$ & $50 \%$ & $48 \%$ & - \\
\hline $\begin{array}{l}\text { Problematic integration with } \\
\text { existing business processes }\end{array}$ & $65 \%$ & $75 \%$ & $73 \%$ & $58 \%$ & $=$ \\
\hline $\begin{array}{l}\text { Lack of one-to-one marketing } \\
\text { experience }\end{array}$ & $68 \%$ & $57 \%$ & $42 \%$ & $41 \%$ & - \\
\hline \multicolumn{6}{|l|}{ Rules and standards } \\
\hline Lack of government regulations & $64 \%$ & $45 \%$ & $52 \%$ & $11 \%$ & - \\
\hline Legal issues / lack of regulation & $79 \%$ & $49 \%$ & $63 \%$ & $49 \%$ & - \\
\hline Lack of industry standards & $64 \%$ & $56 \%$ & $63 \%$ & $50 \%$ & - \\
\hline \multicolumn{6}{|l|}{ Costs } \\
\hline Too high costs / Investments & $78 \%$ & $55 \%$ & $69 \%$ & $76 \%$ & $=$ \\
\hline $\begin{array}{l}\text { Lack of internal budget / Fund- } \\
\text { ing }\end{array}$ & $61 \%$ & $46 \%$ & $53 \%$ & $62 \%$ & $=$ \\
\hline \multicolumn{6}{|l|}{ Awareness } \\
\hline $\begin{array}{l}\text { Lack of e-business awareness in } \\
\text { my company }\end{array}$ & $78 \%$ & $48 \%$ & $43 \%$ & $43 \%$ & - \\
\hline Lack of e-business strategy & $73 \%$ & $64 \%$ & $61 \%$ & $45 \%$ & - \\
\hline $\begin{array}{l}\text { Lack of internal top management } \\
\text { support }\end{array}$ & $57 \%$ & $29 \%$ & $33 \%$ & $45 \%$ & - \\
\hline
\end{tabular}

$\left(^{*}\right)$ = means keeping at the same level ; - means becoming less strong

According to the figure below (Figure 6), there are some significant differences between SMEs and large companies in rating barriers. Large companies generally experience higher levels of impediments (74\%) than SMEs (47\%). 


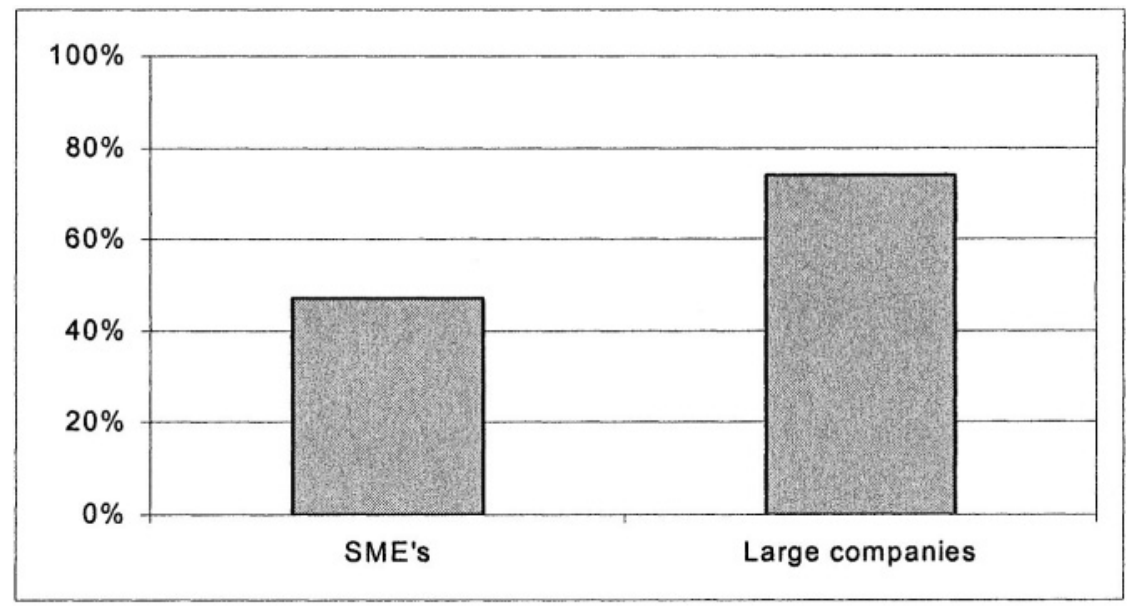

Figure 6. The importance of barriers for SMEs and large companies

The larger the enterprise, the more the aspects such as 'rules and standards' and 'lack of awareness' are seen as important barriers. This shows that the implementation of new Internet technologies are far more complex or this shows that large companies have a higher perception, consciousness and planning attitude in their companies than SMEs do in that respect. Since Internet technologies are expensive, costs and 'safety and security' represent the most important thresholds to develop and implement these technologies in SMEs. Compared to the barriers of large companies, some aspects, which are not mentioned in this study, are especially problematic for SMEs. Some of these barriers include lack of qualified personnel, risk of loss, partners' ecommerce readiness, lack of business models and legal issues (CommerceNet study, 2000).

From 1999 until 2002, we can see, on one hand, that the barriers became generally less important or at least stayed at about the same level for large companies. On the other hand, the perception of costs and safety factors as impediments for further investing in e-business seems to be increased in the perception of SME management (Table 10). 
Table 10. The importance of barriers in SMEs and large companies (1999-2002)

\begin{tabular}{|c|c|c|c|c|c|c|c|c|c|c|}
\hline & \multicolumn{10}{|c|}{ Importance of barriers } \\
\hline & \multicolumn{2}{|c|}{$\begin{array}{c}1999 \\
\text { Very + } \\
\text { Rather } \\
\text { important } \\
\text { barrier }\end{array}$} & \multicolumn{2}{|c|}{$\begin{array}{c}2000 \\
\text { Very }+ \\
\text { Rather } \\
\text { important } \\
\text { barrier }\end{array}$} & \multicolumn{2}{|c|}{$\begin{array}{c}2001 \\
\text { Very }+ \\
\text { Rather } \\
\text { important } \\
\text { barrier }\end{array}$} & \multicolumn{2}{|c|}{$\begin{array}{c}2002 \\
\text { Very }+ \\
\text { Rather } \\
\text { important } \\
\text { barrier }\end{array}$} & \multicolumn{2}{|c|}{ Changes } \\
\hline & $\sum_{\infty}$ & 总 & $\sum_{\infty}^{\infty}$ & 总 & $\sum_{\infty}^{\infty}$ & 总 & 虍 & 总 & $\sum_{n}^{\infty}$ & 橤 \\
\hline & $\begin{array}{l}N= \\
42\end{array}$ & $\begin{array}{l}N= \\
36\end{array}$ & $\begin{array}{l}N= \\
26\end{array}$ & $\begin{array}{l}\mathrm{N}= \\
30\end{array}$ & $\begin{array}{l}\mathrm{N}= \\
19\end{array}$ & $\begin{array}{l}\mathrm{N}= \\
33\end{array}$ & $\begin{array}{l}\mathrm{N}= \\
30\end{array}$ & $\begin{array}{l}\mathrm{N}= \\
19\end{array}$ & & \\
\hline \multicolumn{11}{|l|}{ Safety } \\
\hline Security & $73 \%$ & $91 \%$ & $74 \%$ & $82 \%$ & $79 \%$ & $88 \%$ & $93 \%$ & $83 \%$ & + & $=$ \\
\hline Privacy (on payments) & $78 \%$ & $94 \%$ & $60 \%$ & $71 \%$ & $63 \%$ & $66 \%$ & $86 \%$ & $72 \%$ & $=$ & $=$ \\
\hline $\begin{array}{l}\text { Fear of cannibalizing / } \\
\text { competing with your exist- } \\
\text { ing business }\end{array}$ & $31 \%$ & $\mathbf{5 5} \%$ & $27 \%$ & $\mathbf{5 0} \%$ & $16 \%$ & $\mathbf{5 2} \%$ & $24 \%$ & $24 \%$ & - & - \\
\hline \multicolumn{11}{|l|}{ Know-how \& technology } \\
\hline Language & $50 \%$ & $48 \%$ & $27 \%$ & $29 \%$ & $26 \%$ & $25 \%$ & $21 \%$ & $12 \%$ & - & - \\
\hline $\begin{array}{l}\text { Lack of ready-to-use soft- } \\
\text { ware solutions }\end{array}$ & $59 \%$ & $71 \%$ & $54 \%$ & $68 \%$ & $79 \%$ & $61 \%$ & $41 \%$ & $39 \%$ & $=$ & - \\
\hline $\begin{array}{l}\text { Lack of internet technol- } \\
\text { ogy know-how / Experi- } \\
\text { ence }\end{array}$ & $64 \%$ & $68 \%$ & $54 \%$ & $61 \%$ & $42 \%$ & $55 \%$ & $40 \%$ & $61 \%$ & - & $=$ \\
\hline $\begin{array}{l}\text { Problematic integration } \\
\text { with existing business } \\
\text { processes }\end{array}$ & $56 \%$ & $74 \%$ & $65 \%$ & $82 \%$ & $\mathbf{5 8} \%$ & $82 \%$ & $57 \%$ & $59 \%$ & $=$ & $=$ \\
\hline $\begin{array}{l}\text { Lack of one-to-one mar- } \\
\text { keting experience }\end{array}$ & $60 \%$ & $76 \%$ & $50 \%$ & $64 \%$ & $53 \%$ & $63 \%$ & $37 \%$ & $47 \%$ & - & - \\
\hline \multicolumn{11}{|l|}{ Rules and standards } \\
\hline $\begin{array}{l}\text { Lack of government regu- } \\
\text { lations }\end{array}$ & $63 \%$ & $65 \%$ & $35 \%$ & $54 \%$ & $44 \%$ & $57 \%$ & $48 \%$ & $56 \%$ & $=$ & - \\
\hline $\begin{array}{l}\text { Legal issues / lack of regu- } \\
\text { lation }\end{array}$ & $73 \%$ & $85 \%$ & $38 \%$ & $59 \%$ & $61 \%$ & $63 \%$ & $46 \%$ & $53 \%$ & $=$ & - \\
\hline Lack of industry standards & $63 \%$ & $65 \%$ & $50 \%$ & $64 \%$ & $63 \%$ & $63 \%$ & $48 \%$ & $53 \%$ & $=$ & - \\
\hline \multicolumn{11}{|l|}{ Costs } \\
\hline $\begin{array}{l}\text { Too high costs / Invest- } \\
\text { ments }\end{array}$ & $79 \%$ & $77 \%$ & $50 \%$ & $61 \%$ & $74 \%$ & $67 \%$ & $78 \%$ & $72 \%$ & $=$ & $=$ \\
\hline $\begin{array}{l}\text { Lack of internal budget / } \\
\text { Funding }\end{array}$ & $56 \%$ & $65 \%$ & $56 \%$ & $39 \%$ & $56 \%$ & $52 \%$ & $64 \%$ & $59 \%$ & + & $=$ \\
\hline
\end{tabular}

continued

$\left(^{*}\right)$ = Means keeping at the same level ; - means becoming less strong

$\left(^{*}\right)$ The figures in bold show significant differences between SMEs and large companies: $t-$ test with a confidence interval of $85 \%$ 


\begin{tabular}{|c|c|c|c|c|c|c|c|c|c|c|}
\hline & \multicolumn{10}{|c|}{ Importance of barriers } \\
\hline & \multicolumn{2}{|c|}{$\begin{array}{c}1999 \\
\text { Very + } \\
\text { Rather } \\
\text { important } \\
\text { barrier }\end{array}$} & \multicolumn{2}{|c|}{$\begin{array}{c}2000 \\
\text { Very + } \\
\text { Rather } \\
\text { important } \\
\text { barrier }\end{array}$} & \multicolumn{2}{|c|}{$\begin{array}{c}2001 \\
\text { Very }+ \\
\text { Rather } \\
\text { important } \\
\text { barrier }\end{array}$} & \multicolumn{2}{|c|}{$\begin{array}{c}2002 \\
\text { Very }+ \\
\text { Rather } \\
\text { important } \\
\text { barrier }\end{array}$} & \multicolumn{2}{|c|}{ Changes } \\
\hline & $\sum_{\infty}^{\infty}$ & $\begin{array}{l}\text { 心 } \\
\text { 哥 }\end{array}$ & $\sum_{\infty}^{\infty}$ & $\begin{array}{l}\text { 品 } \\
\text { 舁 }\end{array}$ & $\sum_{\infty}^{\Perp}$ & $\begin{array}{l}\text { 吅 } \\
\text { స్త }\end{array}$ & $\sum_{\infty}^{n}$ & $\begin{array}{l}\text { 吅 } \\
\text { స్త్త }\end{array}$ & $\sum_{\mathscr{N}}$ & $\begin{array}{l}\text { 品 } \\
\text { స్త్త }\end{array}$ \\
\hline & $\begin{array}{l}N= \\
42\end{array}$ & $\begin{array}{l}N= \\
36\end{array}$ & $\begin{array}{l}N= \\
26\end{array}$ & $\begin{array}{l}\mathrm{N}= \\
30\end{array}$ & $\begin{array}{l}\mathrm{N}= \\
19\end{array}$ & $\begin{array}{l}\mathrm{N}= \\
33\end{array}$ & $\begin{array}{l}\mathrm{N}= \\
30\end{array}$ & $\begin{array}{l}\mathrm{N}= \\
19\end{array}$ & & \\
\hline \multicolumn{11}{|l|}{ Awareness } \\
\hline $\begin{array}{l}\text { Lack of e-business aware- } \\
\text { ness in my company }\end{array}$ & $74 \%$ & $83 \%$ & $35 \%$ & $64 \%$ & $42 \%$ & $55 \%$ & $29 \%$ & $69 \%$ & - & $=$ \\
\hline Lack of e-business strategy & $72 \%$ & $74 \%$ & $62 \%$ & $64 \%$ & $68 \%$ & $56 \%$ & $39 \%$ & $53 \%$ & - & $=$ \\
\hline $\begin{array}{l}\text { Lack of internal top man- } \\
\text { agement support }\end{array}$ & $49 \%$ & $67 \%$ & $27 \%$ & $32 \%$ & $32 \%$ & $34 \%$ & $30 \%$ & $67 \%$ & - & $=$ \\
\hline
\end{tabular}

$\left({ }^{*}\right)=$ Means keeping at the same level ; - means becoming less strong

(*) The figures in bold show significant differences between SMEs and large companies: $t-$ test with a confidence interval of $85 \%$

\section{CONCLUSION}

E-business shows -also in this series of surveys made in Belgium- a hype-cycle with a peak in 2000. This hype cycle strengthened our believe that companies were much too willing to believe in the promises of the new Internet economy without really thinking about Internet-ability.

In this survey work, first of all a longitudinal analysis of the e-business situation of Belgian companies is described (1999-2002); secondly a comparison of drivers and barriers for e-business adoption between large companies and SMEs was made (under 500 employees being an SME in a wider European context). Research showed that larger companies more often formalized their Internet technology objectives into an e-business plan than SMEs. This poor formalization explains why SMEs lag behind.

Internet technologies affect all processes of an organization: selling, finding partners, marketing, transfer documents, after-sales service, etc. But according to a report of the French Ministry of Economic Affairs, Finance and Industry few enterprises, large and smaller ones, are aware of all the opportunities the Internet has to offer. Moreover the 2004 e-readiness report of the Economist Intelligence Unit stated that Belgium is not yet completely ready for the internet-economy, with only a 17 th place out of 60 countries over the world. The Internet is not something that can be neglected. Essential to the 
success of Internet-adoption, is the capacity of companies to adopt and innovate in order to face international competition.

The Public Governments have an important role to play in order to create a favorable context for Internet-adoption (especially for SMEs), elevate the barriers, and more importantly to integrate these necessary evolutions in their own organizations when they act as client, supplier or partner for other companies.

Business Schools, Universities, government agencies and various SME stakeholders can help to overcome this threshold and can advise, collaborate and provide services to build an environment for aggressive e-business adoption in SMEs (Jutla en Weatherbee, 2002). Coordination, particularly formal programs between government organizations and IT industry, is key to success (Economist Intelligence Unit, 2004). It is important that all stakeholders cooperate to develop proper e-governance for a region or a country in order to promote e-business activities and overcome the barriers to e-business adoption. Furthermore, SMEs have to create a multiple e-business approach to create a more holistic view. This holistic view can be created by business cases on e-business. This can also be boosted by Business Schools and Universities.

As far as the drivers concerned in this study, it is shown that whatever the size of these companies, interest in e-business is very much oriented towards obtaining cost-reduction in some of the major processes. It can be seen that other drivers, such as the improvement of customer service, but especially collaboration and cooperation are sometimes of greater importance. For some processes and some application fields, this study shows a widening gap between SMEs and large companies in the importance of e-business over time.

To have a more detailed view on the drivers and barriers that influence the Internet-ability, this study made an analysis about the differences between larger and smaller companies for a limited number of variables. We can conclude that larger companies are mainly driven by cost-savings to implement Internet technologies whereas SMEs are more driven by improving cooperation with suppliers and clients than by cost-cutting only. This is in contradiction to some other views on SMEs. Levy, Powell and Yetton see an e-business investment as either a driver for costs or as a driver for growth. Prananto, McKay and Marshall, on the other hand, believe that cost is the main barrier for SMEs' e-business initiatives. Another phenomenon is that barriers for e-business became less strong during the last four years. Only security and costs stayed large obstructions for e-business investments. This study shows that these barriers are higher in large companies than in SMEs. Furthermore, we can observe that larger companies attach more importance to e-business, see more opportunities in translating their e-business strategy 
into a formal plan and are less trend sensitive concerning e-business matters than SMEs.

The study however has to be careful with generalizing its findings since each year is based on a rather small sample of companies of both sizes. Further analysis on this Internet-ability concept and on studying drivers and barriers over time need to be done for a larger sample, before making any strong and final conclusion in this subject. Another remark is that this study does not measure the e-business capabilities that should be taken into account before investigating the drivers and barriers. We hope however that the material of this research might have an influence on the formulation of new hypotheses withheld in other studies on the subject of e-business adoption and implementation.

\section{REFERENCES}

Armit, R., Zott, C. (2001), 'Value creation in e-business', Strategic Management Journal, Jun/Jul 2001, Vol.22, Iss.6/7, pp.493-520.

CommerceNet Study (2000), 'Survey: Barriers to Electronic Commerce', $<$ http://osiris.sund.ac.uk/ cs0pco/iec/CommerceNet2000SurveyBarrierstoEC.doc>

Deschoolmeester D. \& Braet O. (2001), 'On the Five Mechanisms for Strategic IS Alignment', Proceedings of the 8th European Conference on Information Technology Evaluation, 17-18 September 2001, Oxford, London, pp. 1-27.

Deschoolmeester D. \& Kortleven C. (2001), 'Internet-ability - On the context \& criteria influencing Internet attractiveness for organisations', EFMD (European Foundation for Management Development), Dublin, 12-14 Sep. 2001.

Economist Intelligence Unit, The 2004 e-readiness rankings, a white paper from the Economist Intelligence Unit in cooperation with IBM Institute for Business Value,

http://www-5.ibm.com/services/uk/pdf/eiu_ereadiness_19april04.pdf

Jutla D., Weatherbee T. (2002), 'Supporting Clear: A Strategy for Small and Medium sized Enterprise Adoption of E-business practices in Atlantic Canada', IFIP World Computer Congress, June 9-11 2002, Copenhagen, Denmark, pp. 169-186.

Levy L., Powell P. and Yetton P. (2002), 'IS alignment in Small Firms: New Paths through the Maze', ECIS, June 16-21 2003, Napoli, Italy.

Ministère de l'Economie, des Finances et de l'Industrie, Ministère délégué à l'Industrie, Internet et Entreprise mirages et opportunités?, Pour un plan d'action, Contribution à l'analyse de l'économie de l'Internet, Rapport de la Mission conduite par Jean-Michel Yolin, 1 January 2004, http://www.telecom.gouv.fr/documents/yolin/1215mirage2004.pdf

OECD (1999), 'Business-to-Business E-commerce: Status Economic Impact and Policy Implications', OECD Working Paper, No.77.

Porter, Michael E., (1980) Competitive Strategy: Techniques for Analysing Industries and Competitors, New York: The Free Press.

Porter, Michael E., Millar, Victor E., (1985), How Information gives you competitive advantage, Harvard Business Review, July-August 1985, Vol.63, Iss. 4, Pg. 149, 12 pgs. 
Prananto A., McKay J. and Marshall P. (2003), 'The spectrum of e-business maturity in Australian SMEs: A Multiple Case study approach to the applicability of the stages of growth for e-business model', ECIS, Napoli, Italy.

PriceWaterhouseCoopers (1999), 'SME E-commerce study, Asia Pacific Economic Cooperation (APEC), Final Report September 24.

Scupola A. (2002), 'Adoption of E-commerce in SMEs: Lessons from Stage Models', IFIP World Computer Congress, June 9-11 2002, Copenhagen, Denmark, pp. 291-308.

Wiseman, C. (1985), 'Strategy and Computers Information Systems as Competitive Weapons.', Dow Jones Irwin, London.

Wiseman, Charles, (1988), Strategic Information Systems: Trends and Challenges over the Next Decade, Information Management Review, Summer 1988, Vol. 4, Iss. 1, pg.9, 8 pgs.

Zhu Kevin, Kraemer Kenneth L. and Xu Sean (2002), A Cross-Country Study of Electronic Business Adoption Using the Technology-Organization-Environment Framework, Center for Research on Information Technology and Organizations (CRITO), University of California, Irvine, ICIS 2002 Best Paper, 15-18 December 2002, Barcelona. 